\title{
Commercial varieties of European plums grown in Hungary, a comparison of promising foreign varieties with the widely grown traditional ones
}

\author{
Kovács, Sz. ${ }^{1}$, Molnár, Á. ${ }^{1}$, Szenci, Gy. ${ }^{2}$ \& Tóth, M. ${ }^{1}$ \\ ${ }^{1}$ Budapesti Corvinus Egyetem, Gyümölcstermö Növények Tanszék \\ ${ }^{2}$ Budapest-Érd, Állami Gyümölcs- és Dísznövénytermesztési Kutató-Fejlesztö Közhasznú Nonprofit Kft.
}

\begin{abstract}
Summary: Observations and investigations performed in laboratory at several growing sites over a period of many years are summarised on established plum varieties as well as on new promising ones concerning their marketing value. The ripening period of plum varieties was enlarged substantially with the appearance of new varieties of extra late maturity ('Elena', 'Tophit', 'Presenta'). The new varieties did not alter the traditional colour, more or less long, violet or blue character of the plum. The most known type, 'Besztercei szilva' with its accustomed taste was followed by the new varieties 'Katinka', 'Tegera', 'Hanita' and 'Presenta'. The fruit size are largely of the medium category, except the early ripening small 'Katinka', whereas the larger and attractive ( $60 \mathrm{~g})$ fruits are represented by the late ripening 'Tophit' and 'Empress'. The stone/fruit ratio was lowest in $3 \%$ ('Tophit') and 6\% ('Besztercei Bt. 2', 'Hanita', 'Jojo', ' 'Čačanska rana') at the other end of the scale. The width and thickness of the fruit flesh between $28 \mathrm{~mm}$ ('Besztercei szilva') and 43-44 mm ('Empress', 'Tophit'). The firmness of the fruit flesh excelled in the late maturity varieties 'Presenta' and 'Tophit' $\left(\sim 4 \mathrm{~kg} / \mathrm{cm}^{2}\right)$. Water soluble solids were $12-13$ Brix\% ('Čačanska rana', 'Katinka', 'Silvia') and 20 Brix\% ('Presenta', 'Tophit'), whereas titrated acids are found between 0.2\% ('Besztercei Bt. 2') and 1.2\% ('Tegera').
\end{abstract}

Key words: plum, time of maturity, pomological properties, yields, content of water soluble solids, acids

\section{Introduction and survey of the literature}

Plum growing is a Hungarian tradition since centuries. Its popularity is founded by its long ripening period and its advantageous fruit characters. Up to the present times, plums for fresh consumption as well as for industrial procession are highly appreciated on the market.

At the moment, the National List of Varieties contains 20 varieties of State Registration, 3 of them belong to the Japanese plum species. The majority of the list is Prunus domestica L.), but the round shape is typical for 'Althann ringló', 'Zöld ringló' and 'Sermina' which are named Prunus $\mathrm{x}$ italica convar. claudiana (i.e. Raineclaudes). The origin of varieties is variable. Three are considered as Hungarian, the rest German, Serbian, Czech, French, Rumanian, Italian (National List of Varieties 2011). The structure of varieties is changing gradually. There is a tendency to prefer varieties, which are more tolerant to the sharka virus, high yielding and autofertile (self-compatible). The majority is a member of "domestic" group (Kovács, 2009).

The plum season lasts in Hungary for almost 3 mounts. The first ripe fruit appears around the end of June, early July by 'Ruth Gerstetter'. The season is ended by 'President' at the mid of September. To the late period belong the varieties with large, firm fruits and high soluble solid content (e.g.
'Stanley', 'President'). The picked fruit is easily stored for fresh consumption over several weeks (Surányi, Erdös, 1998; Surányi, Erdös, 2006; Szabó, 2001), where the role of new German varieties is decisive (Szabó, 2001; Surányi, Erdös, 1998; Jacob, 1998, 2002; Hartmann, 1998).

For the grower, one of the most important faculties of the variety is the fruit mass. According to literature we may distinguish small (less than $25 \mathrm{~g}$ ), medium (25-35 g), large (35-45 g) and very large (more than $45 \mathrm{~g}$ ) categories (Szabó, 2001). However, on the market, the diameter of the fruit is considered. For fresh consumption the large fruit has a diameter of $30-35 \mathrm{~mm}$, the rest ought to have $25-28 \mathrm{~mm}$ (Szenci, 2006).

Large varieties (mainly in the early season) plums and raineclaudes are sold preferably for fresh consumption. Medium and small fruits are ready for deep cooling and industrial processing, where the high content of soluble solids is highly appreciated (Szabó, 2001).

The nutritional value of the plum is due to its chemical composition. Compared with other fruits of the moderate climate, the energy content is considerable $(244 \mathrm{~kJ} / 100 \mathrm{~g})$. Carbonhydrates are 10-18\%, but the alcohols (like sorbite, xylite) are also considerable. The acid are mediocre (0.5$1.4 \%$ ), where malic acid prevails but we may find tartaric, succinic and citric acids too. (Rodler, 2005; Surányi, 2006) 
Tóth (1957) and Surányi (1990, not published) measured as lowest soluble solids in 'Grand Prix' and 'Sasbachi korai' (14\%), and highest in 'Čačanska secer' (23\%) and in 'Violaszín ringló' (27\%) varieties. Lowest acid content was in 'Nancy mirabella', 'Ageni' 'Besztercei szilva' (0.4-0.5\%), whereas highest acids in 'Silvia' (1.3\%) and in 'Nagyherceg' (1.7\%) (Surányi, 1980; Szabó \& Nyéki, 2006c). As a rule, late ripening varieties contain mor soluble solids and les acids (Surányi, 2006).

\section{Objectives set}

We aimed to compare the new and potentially promising plum varieties with the traditional and appreciated ones form the point of view of their marketing value. For that purpose, utilised the bulk of data accumulated during many years on a couple of growing sites and analysed in the laboratories during our practice. rendelkezésünkre.

\section{Material and methods}

The investigation pointed on commercial value of fruit of plum varieties started with 2006 in the plantation of the BCE KTK Experimental Farm, collection of varieties at Szigetcsép, the plantation of the Kevefruct ZRt, paralleling with 2007, 2008 in the fields of the non-profit Fruits and Decorative Plants Kft at Érd-Elvira. With 2009, the Budapest Corvin University, Dpt. Fruit Growing contributed on the Experimental Farm at Soroksár to the project. The dates and conditions of field observations are presented in Table 1.

Plum trees have been grown on Myrobalan rootstocks in a $6 \times 4 \mathrm{~m}$ planting design (Szigetcsép, Érd-Elvira), or $5 \times 3$ m (Soroksár, Ráckeve). Planting dates are at Szigetcsép in autumn 1991 and spring 1992. At Érd-Elvira, the variety collection started in 1996 and 1998, and with new varieties ('Jojo', 'Elena', 'Presenta', 'Tegera') in 2004. The plantation of Ráckeve started in 2002-2003, at Soroksár, the gene bank in autumn 2004 and 2005.

At Szigetcsép no pruning has been performed, consequently, trees showed their their natural habits. For the purpose of maintaining the fruiting, dense crowns have been thinned. At Érd-Elvira and Soroksár, the trees have been trained to free spindle crown.

At Szigetcsép, the space between the rows has been co-vered with sod and mown regularly. The plantation was not irrigated during the season of observations, and phytosanitary treatments were minimised. The collection has been abolished in the winter of 1996. The intensive plantation at Ráckeve and the model farm of Soroksár with the collection of varieties was also covered by sod and irrigated occasionally. Fertilisation was performed on the basis of soil- and leaf-analysis. (Oral informations of Béla Bódis 2011; Gyözö Szenci and Miklós Makay Miklós, 2010).

The study dealt with varieties significant in Hungarian markets: 'Althann ringló', 'Besztercei szilva', 'Bluefre',
'Čačanska lepotica', 'Čačanska rana', 'Čačanska rodna', 'President', 'Silvia', 'Stanley', 'Valjevka'. The promising, new foreign varieties are from Germany: 'Elena', 'Hanita', 'Jojo', 'Katinka', 'Presenta', 'Tegera', 'Tophit' and from the USA 'Empress'.

For the morphological, physical and chemical characterisation, fruits have been used randomly 30 per variety at the $85-90 \%$ stage of ripening. The samples have been processed within 1-2 days after storing in $5-7{ }^{\circ} \mathrm{C}$ cool store. In the case of 'Empress', the sampling was performed according to the practice of the company, at 75-80\% ripeness.

Morphology (form of the fruit, colour of skin and of flesh, parting of stone) physical (mass, width, thickness, stone/ fruit ratio, flesh firmness), chemical (water soluble solids, vízoldható szárazanyag-tartalom (Brix\%); titrable acids) analyses were performed in the laboratory at the Department of Fruit Growing of the University. Water soluble solids are determined according to the Codex Alimentarius 3-1-558/93; whereas the titrable acids according to the standards of MSZ EN 12147:1998.

Evaluation and processing of data ensued by the Excel program of the computer.

Table 1. Field observations, sampling sites and dates

\begin{tabular}{|c|c|c|}
\hline Variety & Site of the analysis & Dates (years) \\
\hline Althann ringló & $\begin{array}{l}\text { Szigetcsép, Érd-Elvira, } \\
\text { Soroksár }\end{array}$ & 2006, 2007, 2009 \\
\hline Besztercei Bt. 2 & Érd-Elvira & 2007 \\
\hline Besztercei Nm. 122 & Érd-Elvira & 2007 \\
\hline Bluefre & Szigetcsép, Érd-Elvira & 2006,2007 \\
\hline Čačanska lepotica & $\begin{array}{l}\text { Ráckeve, Szigetcsép, } \\
\text { Érd-Elvira, Soroksár }\end{array}$ & 2006-2011 \\
\hline Čačanska rana & Szigetcsép, Érd-Elvira & 2006-2008 \\
\hline Čačanska rodna & $\begin{array}{l}\text { Szigetcsép, Érd-Elvira, } \\
\text { Soroksár }\end{array}$ & 2006, 2007 2010, 2011 \\
\hline Elena & $\begin{array}{l}\text { Ráckeve, Érd-Elvira, } \\
\text { Soroksár }\end{array}$ & 2006-2009 \\
\hline Empress & Ráckeve & 2006 \\
\hline Hanita & Ráckeve, Érd-Elvira & 2006-2008 \\
\hline Jojo & Érd-Elvira, Soroksár & $2007-2011$ \\
\hline Katinka & Ráckeve, Érd-Elvira & 2006-2008 \\
\hline Presenta & Érd-Elvira, Soroksár & 2008-2009 \\
\hline President & $\begin{array}{l}\text { Szigetcsép, Érd-Elvira, } \\
\text { Soroksár }\end{array}$ & 2006-2009 \\
\hline Silvia & $\begin{array}{l}\text { Ráckeve, Szigetcsép, } \\
\text { Érd-Elvira }\end{array}$ & 2006, 2007 \\
\hline Stanley & $\begin{array}{l}\text { Ráckeve, Szigetcsép } \\
\text { Érd-Elvira, Soroksár }\end{array}$ & 2006-2009 \\
\hline Tegera & Érd-Elvira & 2008 \\
\hline Tophit & Soroksár & 2009 \\
\hline Valjevka & Érd-Elvira & 2007 \\
\hline
\end{tabular}

\section{Results and discussion}

The season of maturity of the commercial varieties grown in Hungary comprises 2.5 months (Figure 1). The first ripe fruits appear during the second ten-day's period of 
July with 'Čačanska rana' érik, whereas the latest around the mid of September with 'President' (Szabó, 2001; Surányi, Erdös, 1998). Among the promising new varieties 'Katinka' is ripening almost at the same time as 'Čačanska rana'. The latest ripening is 'Presenta' in the mid and the end of September. Figure 1 shows how the plum season is prolonged by late ripening varieties. Favourable (dry and hot) weather allowed a harvest up to the end of September.

The registered dates of commercial varieties coincide with the data published by Szabó (2004) - excepte the early 'Čačanska rana' and the mid-season 'Čačanska lepotica' and 'Silvia'. The three latter varieties proved to be earlier by some days than indicated by Szabó. For the promising foreign varieties, earlier data are referred to Szabó, 2004; Surányi, Erdős, 1998 as well as own observations concerning 'Katinka' and 'Tophit' varieties (earlier ripening). Our observations indicated that 'Empress' and 'Stanley' was almost coincident in ripeness. However Szabó (2004) told that its maturity was later, i.e. mid of September.

According to our experiences, the ripening process of the lasts more or less 7-10 (14) days. A quick ripening (7 day) period is found in 'Čačanska rana', 'Tegera' and 'Empress' varieties, whereas longer periods (10-12 days) are typical for 'Katinka', 'Čačanska lepotica', 'Jojo', 'Stanley', 'Elena' and 'Presenta'. 'Čačanskaa rana' is ripening quickly as proved by Kállayné (2000).

\begin{tabular}{|c|c|c|c|c|c|c|c|c|c|}
\hline Month & \multicolumn{3}{|c|}{ July } & \multicolumn{3}{|c|}{ August } & \multicolumn{3}{|c|}{ September } \\
\hline Variety & 1 & 2 & 3 & 1 & 2 & 3 & 1 & 2 & 3 \\
\hline \multicolumn{10}{|c|}{ Traditional varieties } \\
\hline \multicolumn{10}{|l|}{ Cacanska rana } \\
\hline \multicolumn{10}{|l|}{ Cacanska lepotica } \\
\hline \multicolumn{10}{|l|}{ Silvia } \\
\hline \multicolumn{10}{|l|}{ Althann ringló } \\
\hline \multicolumn{10}{|l|}{ Cacanska rodna } \\
\hline \multicolumn{10}{|l|}{ Valjevka } \\
\hline \multicolumn{10}{|l|}{ Stanley } \\
\hline \multicolumn{10}{|l|}{ Bluefre } \\
\hline \multicolumn{10}{|l|}{ Besztercei szilva klónok } \\
\hline \multirow{2}{*}{\multicolumn{10}{|c|}{ Promising new foreign varietes }} \\
\hline \multicolumn{9}{|c|}{ Promising new foreign varietes } & \\
\hline \multicolumn{10}{|l|}{ Katinka } \\
\hline \multicolumn{10}{|l|}{ Tegera } \\
\hline \multicolumn{10}{|l|}{ Hanita } \\
\hline \multicolumn{10}{|l|}{ Empress } \\
\hline \multicolumn{10}{|l|}{ Jojo } \\
\hline \multicolumn{10}{|l|}{ Elena } \\
\hline \multicolumn{10}{|l|}{ Tophit } \\
\hline Presenta & & & & & & & & & \\
\hline
\end{tabular}

Figure 1. Periods of maturity in plum varieties

The main morphological characteristics are presented in Table 2. Fruits of 'Althann ringló' are slightly flattened globes, on the skin, the covering colour is purplish red. The rest of varieties have fruits of more or less long (oval) shape with blue or purple skin. The flesh colour changes gradually from greenish to yellowish colour. The promising new varieties did not change the general tendencies of that nature.
Varieties are generally free stone types, but 'Čačanska rana' and 'Stanley' start to have free-stones during the ripening period. Several authors (Surányi, Erdös, 2006; Beschreibende Sortenliste, 1997; Kállayné, 2000; Szabó, 2001) mentioned that 'Stanley' has free stones at full maturity. Hartmann (1998) mentioned that 'Presenta' has in some years free stones, however, we consider that variety as variably half-free stone type. Harsányi (1979) stated that 'Althann ringló' fruits are of clingstone type if infected by Plum Pox virus. The same has been observed in the variety collection at Soroksár. Half clingstone fruits are mentioned in the List Beschreibende Sortenliste (1997) as for 'President'; Surányi \& Erdös (1998) for 'Silvia', Hartmann (2002) mentioned the same for 'Hanita' in some years. Those three varieties are according to Hungarian experiences free stone types.

The Serbian varieties bred at Čačak: 'Čačanska lepotica' and 'Čačanska rana' are inclined to gummosis (Surányi \& Erdös, 2006; Kállayné, 2000; Szabó, 2001), but our experiences proved it in 'Čačanska lepotica' only.

Symptoms of sunburn appeared on 'Čačanska lepotica' and 'Stanley' sometimes. During the summer, high temperatures are eligible to cause it, not only on the skin but also in the fruit flesh. Hartmann $(2008,2010)$ stated that 'Čačanska lepotica' is especially sensitive to sunburn. At Érd-elvira, 'Čačanska lepotica' trees showed symptoms in 2007. Szabó (1991) observed sunburn in 'Čačanska rodna' fruits.

At Soroksár, the flesh of 'Althann ringló' fruits showed flesh browning symptoms This has been mentioned by Surányi \& Erdös (2006), Kállayné (2000) and Szabó (2001). Flesh browning may caused by weather (heath) but strong Plum Pox virus infection with similar symptoms (Hartmann, 2008, 2010).

The taste of the fruits examined was delicious sweet-sour. Especially attractive taste could be attributed to 'Besz-tercei szilva', then also to 'Katinka', 'Tegera', 'Hanita' and 'Presenta'. The taste of 'Besztercei szilva' is recognised by other authors as met also in German varieties in Beschreibende Sortenliste (1997), Hartmann (1998) and Jacob (2002) too. We found the taste as by comparison that 'Čačanska lepotica', 'Silvia', 'President' and 'Valjevka' fruits as undistinctive. 'President', 'Čačanska lepotica' and 'Silvia' were rated by several authors as semi distinctive (Harsányi, 1979; Surányi \& Erdős, 2006; Kállayné, 2000; Szabó, 2001). 'Valjevka' on the other hand have been judged to be juiceless but as tasting well. The intense cultivation threatens its value if the growing site is dry (Surányi \& Erdös, 2006; Beschreibende Sortenliste, 1997). In the background of our rating, we have to recognise that the collection of varieties at Érd-elvira is maintained under rather extensive conditions.

Table 2 is designed to give more exact, measured data for the shape-characters shown in Table 3. As visible, the formindex of fruits for the variety 'Althann ringlo' is exceptionally round, whereas the majority has more or less long oval fruits. Less elongated are fruits of 'Silvia', 'Bluefre', 'Čačanska lepotica', 'Presenta' and 'Tophit', most elongated are 'Valjevka', 'Stanley' and 'Jojo'. The form-index of plum fruits was rarely treated by the literature. Details are found in papers 
Table 2. Main morphological traits of fruits in plum varieties

\begin{tabular}{|c|c|c|c|}
\hline variety & form of fruits & $\begin{array}{l}\text { covering } \\
\text { colour of } \\
\text { fruit skin }\end{array}$ & $\begin{array}{l}\text { colour of the } \\
\text { fruit flesh }\end{array}$ \\
\hline \multicolumn{4}{|c|}{ traditional varieties } \\
\hline Althann ringló & flattened round & purplish red & orange yellow \\
\hline Besztercei Bt. 2 & Elliptic & dark blue & yellow \\
\hline Besztercei Nm. 122 & Elliptic & dark blue & yellow \\
\hline Bluefre & $\begin{array}{l}\text { slightly elongated, } \\
\text { asymmetric }\end{array}$ & dark blue & $\begin{array}{l}\text { greenish } \\
\text { yellow }\end{array}$ \\
\hline ‘Čačanska lepotica & slightly elongated & $\begin{array}{l}\text { dark purplish } \\
\text { blue }\end{array}$ & $\begin{array}{l}\text { greenish } \\
\text { yellow }\end{array}$ \\
\hline ‘Čačanska rana & Oval & purplish blue & yellow \\
\hline ‘Čačanska rodna & Elliptic & purplish blue & yellow \\
\hline President & reversed oval & purple & orange yellow \\
\hline Silvia & slightly elongated & purplish blue & yellow \\
\hline Stanley & oval & dark blue & yellow \\
\hline Valjevka & Oval & dark blue & yellow \\
\hline \multicolumn{4}{|c|}{ promising new foreign varieties } \\
\hline Elena & reversed oval & dark blue & $\begin{array}{l}\text { yellowish } \\
\text { green }\end{array}$ \\
\hline Empress & Elliptic & $\begin{array}{l}\text { dark purplish } \\
\text { blue }\end{array}$ & $\begin{array}{l}\text { greenish } \\
\text { yellow }\end{array}$ \\
\hline Hanita & Oval & purplish blue & $\begin{array}{l}\text { yellowish } \\
\text { green }\end{array}$ \\
\hline Jojo & Elliptic & dark blue & golden yellow \\
\hline Katinka & Elongated & purplish blue & $\begin{array}{l}\text { greenish } \\
\text { yellow, yellow }\end{array}$ \\
\hline Presenta & elliptic & purple & yellow \\
\hline Tegera & reversed oval & $\begin{array}{l}\text { dark purplish } \\
\text { blue }\end{array}$ & orange if ripe \\
\hline Tophit & $\begin{array}{l}\text { slightly } \\
\text { elongated }\end{array}$ & purple & orange if ripe \\
\hline
\end{tabular}

of Harsányi (1979) and Brózik (1959) referring to varieties grown earlier in Hungary. Data dealing with 'Althann ringló' fruits agrees with ours. 'Stanley' and two items of 'Besztercei szilva' clones proved to be different from the published data, namely, ours were less elongated than those.

Brózik (1959) classified plum varieties according to the length of the fruit stem: very short $(<10 \mathrm{~mm})$, short $(10$ $15 \mathrm{~mm})$, mediocre (15-20 mm), long (20-25 mm) and very long $(25 \mathrm{~mm}<)$. The shortest stems was found in 'Hanita' $(12.9 \mathrm{~mm})$, the longest in 'Bluefre' $(21.7 \mathrm{~mm})$ and 'Čačanska rodna' (20.4 mm) (Table 3). Most varieties have fruit stems around $14 \mathrm{~mm}$ length. Like the form-index, fruit stem length are neglected topics in the literature (Harsányi, 1979; Brózik, 1959). Authors rated 'Althann ringló', 'Besztercei szilva' and 'Stanley' as having stems of mediocre length, but our own measurements put them rather to the short stem category.

European plums altogether have a relatively high stone/ fruit ratio (4-5-6\%). Measured data are found in publications of Brózik (1959), Kállayné (2000), Szabó (2001), Dénes (1991), Ogasanovic et al. (1994) and Szymczak \& Plocharski (1998). Our original data are presented in Table 3. Lowest values $(3 \%)$ are found in 'Tophit'. This category is $(\sim 4 \%)$ valid for 'Althann ringló, 'Besztercei Nm. 122', 'Bluefre' and 'Čačanska lepotica'. Highest values $(\sim 6 \%)$ are found in 'Besztercei Bt. 2', 'Hanita', 'Jojo' and 'Čačanska rana'. Relativly high ratios ( 5,5\%) typical for 'Stanley', 'Tegera', 'Valjevka', 'Čačanska rodna' and 'Katinka'.

A comparison with published data proved the validity of our study in the case of 'Althann ringló', 'Čačanska lepotica', 'Čačanska rana' and 'Bluefre'. Ogasanovic et al. (1994) published similar values in 'Valjevka', however, other varieties ('Čačanska lepotica', 'Čačanska rana', 'Čačanska rodna') produced higher values in our study. 'Stanley' and 'Empress' produced higher values than published by Cinquanta et al. (2002). Data of 'Besztercei Nm. 122' clone coincide with Brózik's (1959), but in the case of 'Besztercei Bt. 2' clone there are differences.

Table 3. Main physical and chemical properties of plum fruits

\begin{tabular}{|c|c|c|c|c|c|}
\hline variety & $\begin{array}{l}\text { shape } \\
\text { index } \\
\text { length/ } \\
\text { width }\end{array}$ & \begin{tabular}{|c|} 
shape \\
index \\
length/ \\
thickness
\end{tabular} & $\begin{array}{c}\text { length of } \\
\text { fruit stem } \\
(\mathrm{mm})\end{array}$ & $\begin{array}{c}\text { stone/ } \\
\text { fruit } \\
\text { ratio }(\%)\end{array}$ & $\begin{array}{l}\text { mass of } \\
\text { the stone } \\
\text { (g) }\end{array}$ \\
\hline \multicolumn{6}{|c|}{ a choice of varieties } \\
\hline Althann ringló & 0.92 & 0.97 & 14.95 & 4.01 & 1.39 \\
\hline Besztercei Bt. 2 & 1.31 & 1.29 & 13.75 & 6.07 & 1.17 \\
\hline Besztercei Nm. 122 & 1.31 & 1.28 & 14.14 & 4.29 & 0.80 \\
\hline Bluefre & 1.17 & 1.15 & 21.70 & 4.14 & 1.87 \\
\hline ‘Čačanska lepotica & 1.17 & 1.16 & 13.94 & 4.40 & 1.71 \\
\hline 'Čačanska rana & 1.30 & 1.23 & no data & 5.89 & 3.00 \\
\hline ‘Čačanska rodna & 1.37 & 1.33 & 20.44 & 5.45 & 1.33 \\
\hline President & 1.19 & 1.18 & 14.87 & 5.12 & 2.01 \\
\hline Silvia & 1.11 & 1.16 & 14.39 & 4.76 & 1.26 \\
\hline Stanley & 1.41 & 1.38 & 18.98 & 5.79 & 1.96 \\
\hline Valjevka & 1.46 & 1.47 & 14.54 & 5.70 & 1.37 \\
\hline \multicolumn{6}{|c|}{ new, promising varieties } \\
\hline Elena & 1.21 & 1.23 & 19.47 & 4.98 & 1.35 \\
\hline Empress & 1.24 & 1.25 & no data & 5.03 & 2.88 \\
\hline Hanita & 1.21 & 1.22 & 12.97 & 5.97 & 1.94 \\
\hline Jojo & 1.38 & 1.41 & 15.26 & 6.04 & 1.96 \\
\hline Katinka & 1.34 & 1.31 & 13.75 & 5.43 & 1.05 \\
\hline Presenta & 1.27 & 1.31 & 17.32 & 4.80 & 1.36 \\
\hline Tegera & 1.33 & 1.28 & no data & 5.70 & 1.81 \\
\hline Tophit & 1.18 & 1.16 & 14.25 & 3.06 & 1.86 \\
\hline
\end{tabular}

The mass of the stone was in most of the varieties around 1.5-2 g (Table 3). Largest stones ( 3 g) are found in 'Čačanska rana' and 'Empress'. The smallest $(1 \mathrm{~g}>)$ is in 'Besztercei Nm. 122' and 'Katinka'. Harsányi (1979) and Surányi \& Erdös (2006) showed information about the size of the stone in a couple of varieties, whereas other authors published too: Ogasanovic et al. (1994), Szymczak \& Plocharski (1998) and Cinquanta et al. (2002). 'Althann 
ringló', 'Silvia', and 'Čačanska rodna' produced the same data as ours. 'President', 'Čačanska rana' and 'Stanley' produced higher values in our study. Our data for 'Čačanska lepotica' and 'Empress' coincided with those of Szymczak \& Plocharski (1998), for 'Valjevka' with that of Ogasanovic et al. (1994). Out of the two clones of 'Besztercei szilva', the 'Besztercei Bt. 2' produced the most similar data found in the literature.

The mass of fruit (size) is the most important character of a variety. The extreme values were $19 \mathrm{~g}$ ('Besztercei szilva') and $60 \mathrm{~g}$ ('Tophit'). The former, our important commercial variety or its two clones are small fruited (Figure 2). Small -mediocre are 'Valjevka', 'Silvia' and 'Čačanska rodna', mediocre: 'Stanley', mediocre-large: 'Althann ringló' and 'Čačanska lepotica'. The large fruit is found in 'President' and 'Bluefre', very large: 'Čačanska rana'. Most of the promising varieties are mediocre-large fruited ('Tegera', 'Hanita', 'Jojo'), or small-mediocre ('Elena', 'Presenta'). Small fruits are typical for the early ripening 'Katinka', whereas the very big fruits are attractive in the late varieties 'Tophit' and 'Empress'.

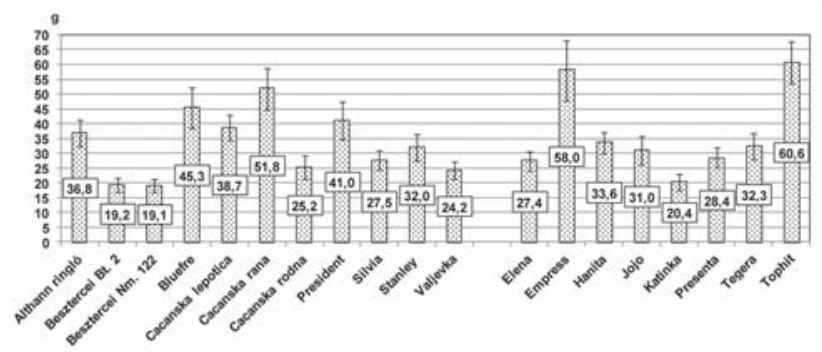

Figure 2. Mean mass of fruits and the standard error of plum varieties

The mass of fruits are difficult to compare with the published data because they are sometimes contradictory (Brózik, 1959; Surányi \& Erdös, 2006; Kállayné, 2000; Szabó, 2001; Klincsek, 2001; Hartmann, 2002; Kemp \& Wustenberghs, 1998; Jacob, 1998, 2002; Ogasanovic et al., 1994; Szymczak \& Plocharski, 1998; Usenik et al., 2008; Cinquanta et al, 2002). One of the reasons may be the annual variation in addition to the growing site effects. In the case of some varieties ('Althann ringló', 'Bluefre', 'Čačanska lepotica', 'Čačanska rana', 'Čačanska rodna', 'President', 'Silvia' and 'Hanita') the authors admit it themselves (Brózik, 1959; Surányi \& Erdös, 2006; Kállayné, 2000; Szabó, 2001; Klincsek, 2001; Hartmann, 2002). Most differences between our and published data are found in 'Bluefre', 'President', 'Čačanska rana', 'Silvia', 'Valjevka' and 'Katinka'. 'Čačanska rana' fruits were bigger, the rest was smaller than the published data.

The width and thickness was almost identical with the published data, i.e. $28 \mathrm{~mm}$ ('Besztercei szilva') and 43-44 mm ('Empress', 'Tophit') (Figure 3). In our study, the small fruits of the clones 'Besztercei szilva', 'Katinka', 'Valjevka' proved to be larger than the prescribed standards $(28-30 \mathrm{~mm})$. Within the mediocre-large - large category ('Althann ringló, 'Čačanska lepotica', 'President') the 38-39 mm values have been marked. In the very big category ('Čačanskarana',
'Empress', 'Tophit') both measures trespassed the $40 \mathrm{~mm}$. Smaller values were registered than published by Brózik, (1959), Surányi \& Erdős (2006), Kállayné (2000), Szabó (2001), Hartmann (1998) and Cinquanta et al. (2002) in the cases of 'Bluefre', 'President', 'Silvia', 'Stanley', 'Empress', 'Katinka' and 'Elena'.

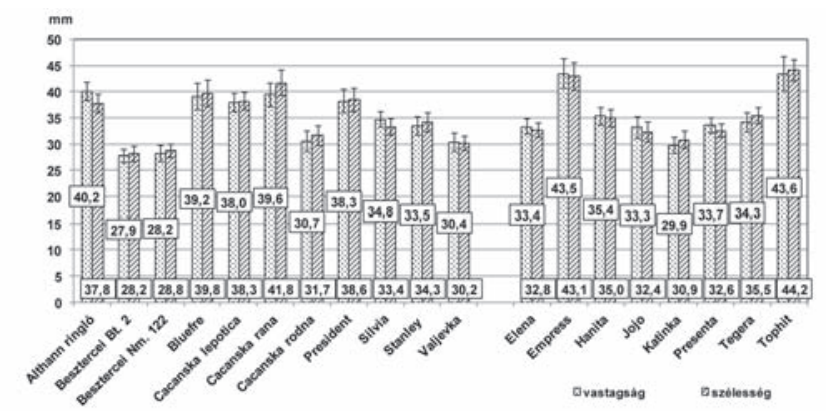

Figure 3. Mean width and thickness of plum fruits with standard errors indicated

The largest (highest) length of fruits was measured in the very large fruit category $(51 \mathrm{~mm}<$ ) of varieties ('Čačanska rana', 'Empress', 'Tophit') (Figure 4). The lowest values in the small fruit category $(40 \mathrm{~mm}>$ ) in 'Besztercei szilva' clones, and in 'Silvia', 'Althann ringló'. In the rest of varieties, the length (height) was between $40-47 \mathrm{~mm}$.

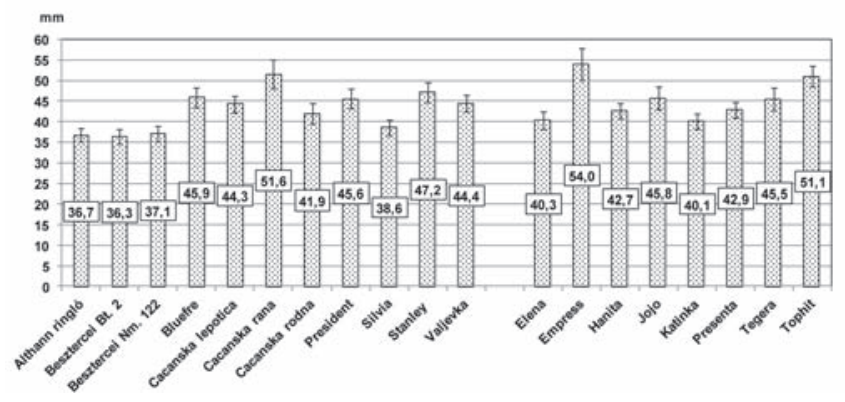

Figure 4. Mean heigth (length) of plum fruits with standard error indicated

Data found in the literature were scanty only 'Althann ringló', 'Besztercei szilva', 'Stanley' and 'Empress' were presented (Brózik, 1959; Harsányi, 1979; Cinquanta et al., 2002). Our results coincide with those of Brózik (1959) Harsányi (1979), but were lower than those of Cinquanta et al. (2002).

In collecting the samples to consider them to be representative, for each sample (site ad year) the standard deviation was also registered. It was stated that largest sampling errors occurred in the size categories of large and very large ('President', 'Bluefre', 'Čačanska rana', 'Empress', 'Tophit') (Figure 2). The same has been experienced in measurements of the height (length) (Figure 4 ) as well as in the width and thickness (Figure 3) values. Errors within samples were high in measurements of height (length) in 'Čačanska rana' and 'Empress' varieties and for thickness in 'Empress', 'Tophit' and 'Bluefre', and for width in 'Čačanska rana', 'Empress' and 'Bluefre' varieties. 
For taking the samples, we strived to concentrate on the ripening stage near to $90 \%$. The sole exception was allowed in case of 'Empress', which is picked for export at the stage of $75-80 \%$ maturity. As a result, we may state that the data of flesh firmness, water soluble solids and titrable acid content were not comparable with other varieties as seen in Figures 5 and 6.

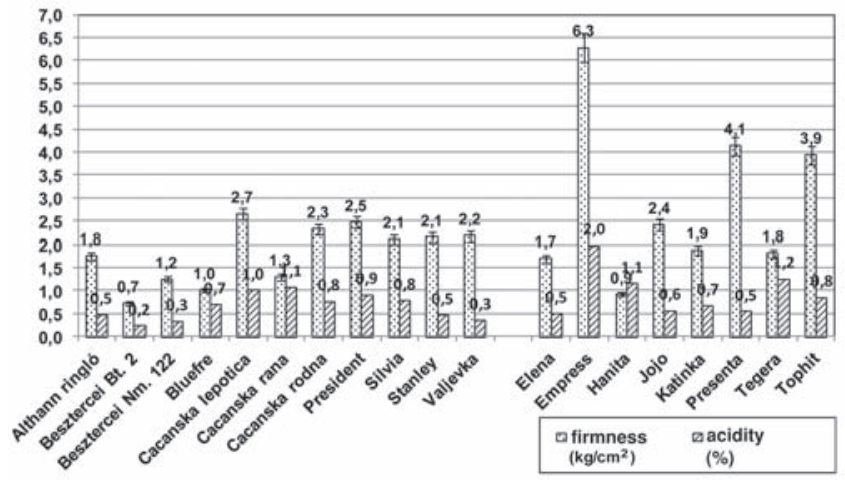

Figure 5. Mean firmness and content of titrable acid content of plum fruits with the standard error of measurements

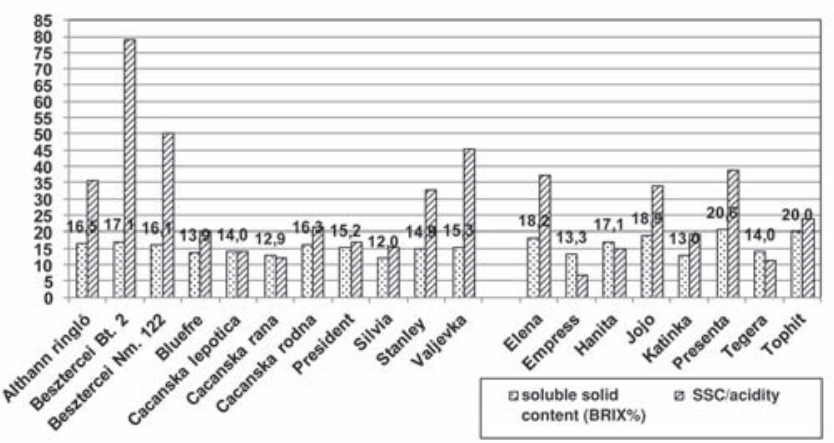

Figure 6. Mean water-soluble solids content and the ratio of soluble solids per titrable acids in plum fruits of varieties

All samples of the rest of varieties were collected at the same degree $(90 \%)$ of maturity, thus their data are comparable. All traditional and new varieties produced values of flesh firmness around $2-2.5 \mathrm{~kg} / \mathrm{cm}^{2}$ (Figure 6). Lowest values were measured $\left(1.5 \mathrm{~kg} / \mathrm{cm}^{2}>\right)$ in 'Besztercei szilva', 'Bluefre' and 'Čačanska rana, and among the new varieties 'Hanita'. Among the late ripening varieties, 'Presenta' and 'Tophit' excelled in firmness $\left(\sim 4 \mathrm{~kg} / \mathrm{cm}^{2}\right)$.

Data related to flesh firmness were different in 'Bluefre' and 'Silvia', but the rest was conform with the published data (Surányi \& Erdös, 2006; Kállayné, 2000; Szabó, 2001; Klincsek, 2001, Usenik et al., 2008). In case of 'Bluefre', we agree with Szabó (2001), whereas in case of 'Silvia', Surányi \& Erdös (2006), Kállayné (2000) and Klincsek (2001) published similar data. In 'Besztercei szilva' clones, the publications reported hard flesh firmness (Harsányi, In Tomcsányi, 1979; Surányi \& Erdős, 2006; Kállayné, 2000; Szabó, 2001). Our own measurements show rather soft flesh for the clones mentioned.
Results of the measurements performed in laboratory, water soluble solids resulted for the collection between 14 and 16 Brix\%. The earliest ripening varieties ('Čačanska rana', 'Katinka'), and the mediocre early ripening 'Silvia' produced values around 12 Brix $\%$. Among the promising new varieties of late maturity produced outstanding, more than 18 Brix\% as 'Jojo', 'Elena', 'Tophit' and 'Presenta' (Figure 7).

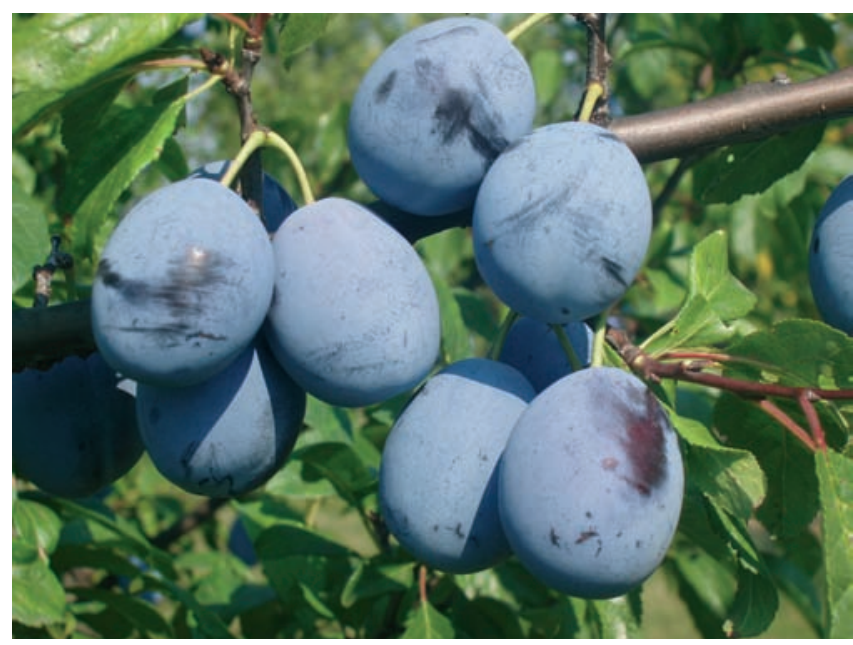

Elena

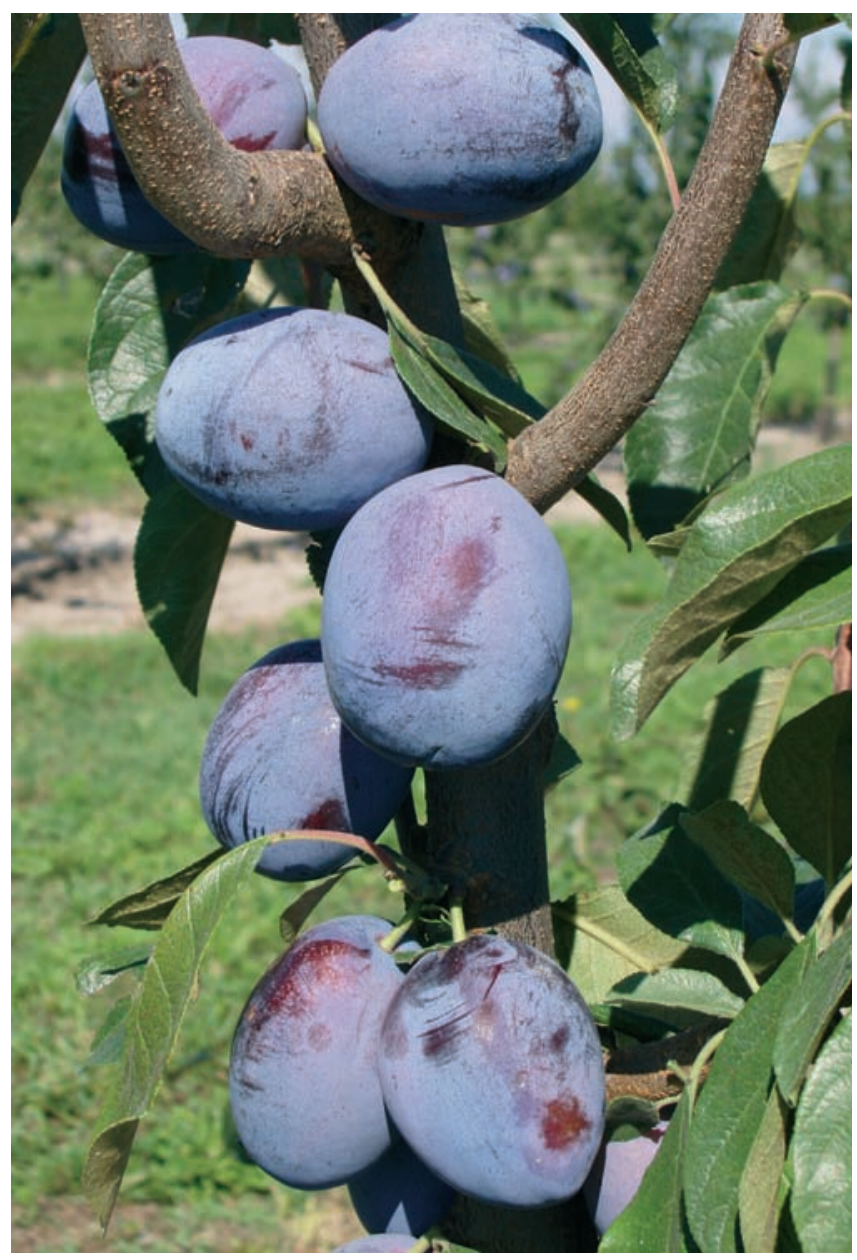

Empress 


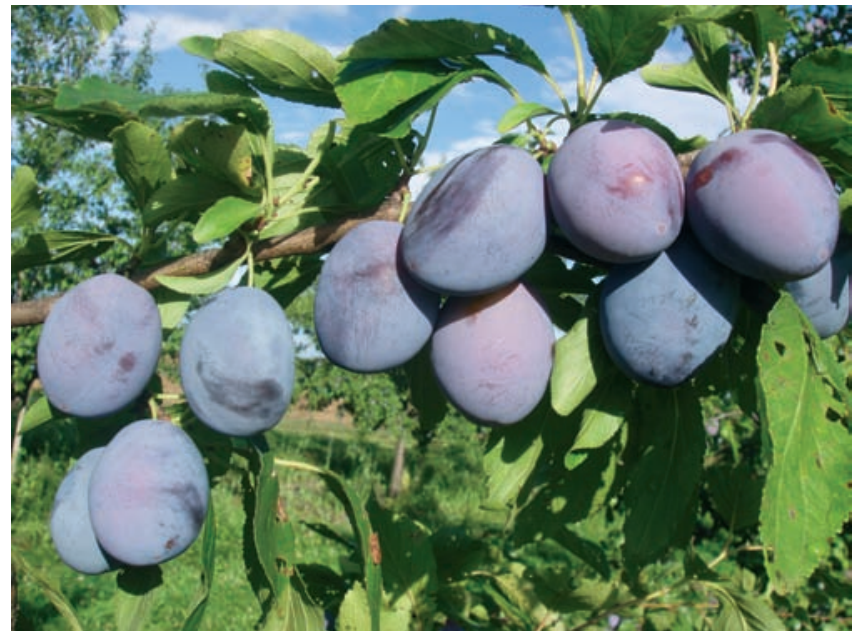

Hanita

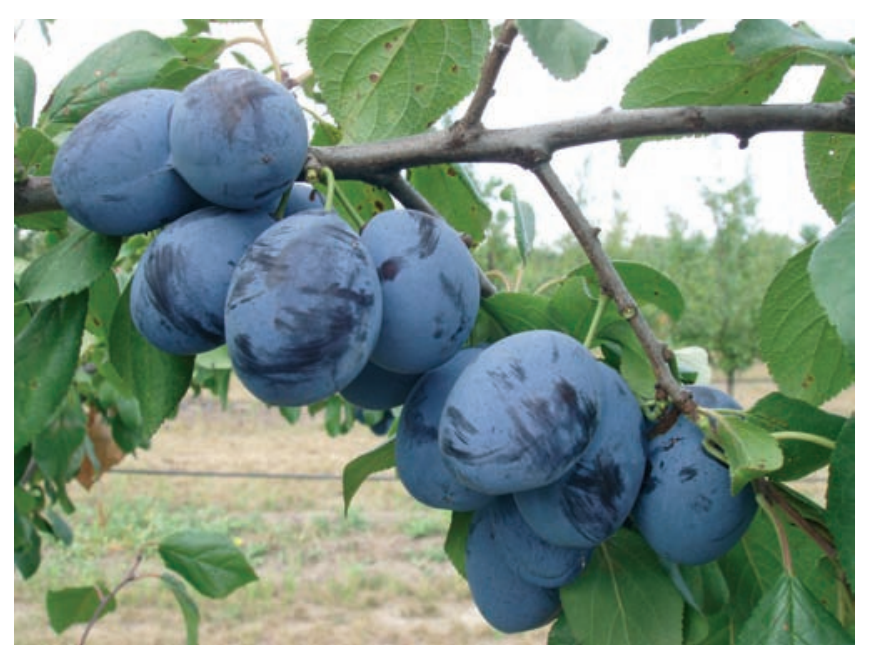

Jojo

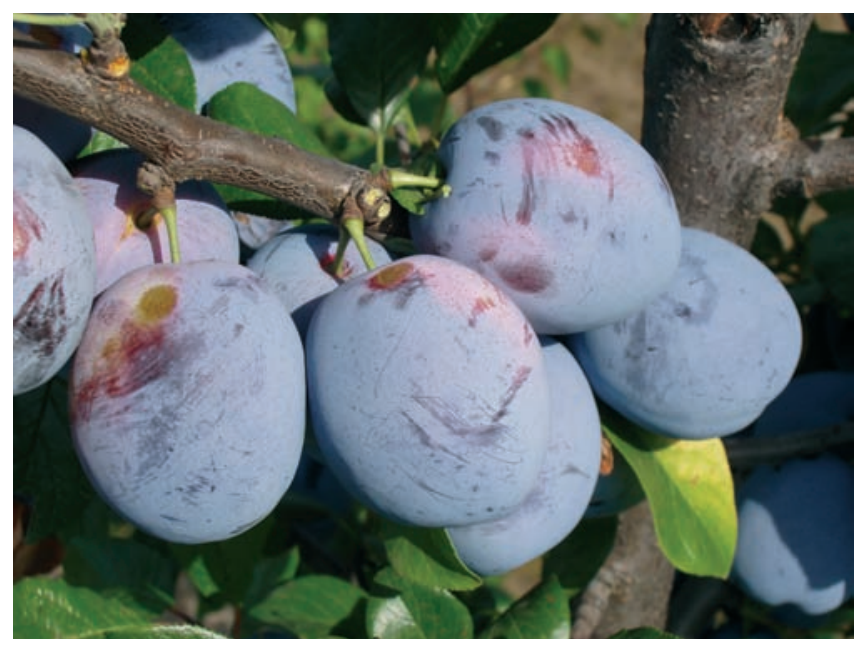

Tophit

Our data were conform with the published ones in the case of the new varieties: 'Hanita', 'Elena', 'Presenta' and 'Tophit', but differ for 'Katinka' and 'Tegera', where our results show lower values than Hartmann (1998) and Jacob (1998) published data. Our results concerning commercial varieties produced lower soluble solids than the published data by Surányi \& Erdös (2006), Surányi (1980, 2009), Klincsek (2001), Kemp, Wustenberghs (1998) and Szymczak \& Plocharski (1998), excepte 'President' and 'Čačanska rodna'. Lower values than those found in our study were registered by Usenik et al. (2008) for 'Jojo' and 'Čačanska rodna'. Kristl et al. (2011) wrote data of 'Hanita' and 'Stanley' being conform with ours, but in case of 'Tophit', our values were lower.

The titrable acid content varied between $0.2 \%$ ('Besztercei Bt. 2') and 1.2\% ('Tegera') (Figure 6). Lowest values, i.e. less than $0.4 \%$ was measured in the two clones of 'Besztercei szilva' and in 'Valjevka'. The highest values (1$1.2 \%$ ) produced 'Tegera', 'Hanita', 'Čačanska lepotica' and 'Čačanska rana'. Except 'President', 'Čačanska lepotica', 'Čačanska rana' and 'Čačanska rodna', titrable acid content was lower in our study than in reports of Surányi \& Erdös, (2006), Surányi, (2009) and Surányi (1980). Our data of 'Čačanska lepotica', 'Čačanska rana' and 'Čačanska rodna' are near those measured by Ogasanovic et al. (1994). 'Stanley', 'Hanita' and 'Tophit' produced higher values according to Kristl et al. (2011).

The ratio of water soluble solids and titrable acid content (Figure 7). The highest values are measured in late ripening varieties. Among the commercial varieties, the two clones of 'Besztercei szilva' were outstanding, but also 'Althann ringló', 'Valjevka' and 'Stanley' are remarkable. Among the promising new varieties, 'Jojo' 'Elena' and 'Presenta' excelled. Lowest values are found in 'Tegera' and 'Čačanska rana'. Our results coincide in 'Stanley', 'Hanita' and 'Tophit' but show better values than published by Kristl et al. (2011).

\section{References}

Beschreibende Sortenliste (1997): Beschreibende Sortenliste Steinobst 1997. Pflaume (Zwetsche). Bundessortenamt, Hannover. 9-51.

Brózik, S. (1959): Termesztett gyümölcsfajtáink 2. Csonthéjastermésűek. Mezőgazdasági Kiadó, Budapest.

Cinquanta, L., Di Matteo. M. \& Esti. M. (2002): Physical pretreatment of plums (Prunus domestica). Part 2. Effect ont he quality characteristics of different prune cultivars. Food Chemistry. 79: 233-238.

Dénes, F. (1991): Minősített szilva. Cacanska lepotica. Kertészet és Szőlészet. 50:4.

Harsányi, J. (1979): Szilva. [In. Tomcsányi P. (ed) Gyümölcsfajtáink. Gyakorlati Pomológia.] Mezőgazdasági Könyvkiadó Vállalat, Budapest. 185-224.

Hartmann, W. (1998): New plum cultivars from Hohenheim. Acta Hoticulturae. 478: 171-174.

Hartmann, W. (2002): 10 Jahre Hanita. Obst \& Garten. 8: 284-286.

Hartmann, W. (2008): A modern szilvatermesztés perspektivikus fajtái. [Gonda I. (szerk.) Magyar szilvatermesztés - stagnálás vagy előrelépés?] Konferencia Füzetek. Debreceni Egyetem. 34-48.

Hartmann, W. (2010): Opening Address. Proceeding of the Nineth International Symposium on Plum and Prune Genetics, Breedig and Pomology. Italy. Acta Horticulturae. 874: 19-23. 
Jacob, H. B. (1998): Top, Topper and Tophit: Three new late ripening plum cultivars for a profitable market. Acta Hoticulturae. 478; 165-167.

Jacob, H. B. (2002): New plum and Mirabelles Varieties out of the Breeding Work and Development in Geisenheim. Acta Hoticulturae. 577: 173-176.

Kállayné, T.-né. (2000): Szilva [In. Brózik, S., Kállayné, T.-né. (ed.) Csonthéjas gyümölcsfajták.] Mezőgazda Kiadó, Budapest. 159-179.

Kemp, H. \& Wustenberghs, H. (1998): Screening of plums and prunes for fresh consumption, 1988-1997. Acta Hoticulturae. 478: 207-216.

Klincsek, P. (2001): Összehasonlító vizsgálatok a Silvia szilvafajtával. Kertgazdaság. 33. (4): 77-80.

Kovács, Sz. (2009): Szilvafajták választékbővítésének lehetőségei Magyarországon. Agrofórum extra 28: 48-50.

Kristl, J., Slekovec, M. \& Tojnko, S. (2011): Extractable antioxidants and non-extractable phenolics in the total antioxidant activity of selected plum cultivars (Prunus domestica L.): Evolution during on-tree ripening. Food Chemistry. 125: 29-34.

Nemzeti Fajtajegyzék (2011): Mezőgazdasági Szakigazgatási Hivatal, Budapest.

Ogasanovic, D., Rankovic, M., Plazinic, R. \& Papic, V. (1994): Performance of newly-bred Čačak plum cultivars and current breeding tendencies. Acta Hoticulturae. 359: 75-81.

Rodler, I. (2005): Új tápanyagtáblázat. Medicina Könyvkiadó Rt., Budapest. 301-323.
Szymczak, J. A. \& Plocharski, W. (1998): Quality of dried prunes in relation to cultivars and technology. Acta Hoticulturae. 478; 319-325.

Surányi, D. (1980): A szedési érettség meghatározása. [In. Tóth E. Surányi, D. (ed.) Szilva.] Mezőgazdasági Kiadó, Budapest. 324-327.

Surányi, D. (2006): A szilva táplálkozás-élettani jelentősége. In. Surányi, D. (ed.) Szilva. Mezőgazda Kiadó, Budapest. 11-14.

Surányi, D. (2009): Újabb kísérleti eredmények és tapasztalatok honosított és szelektált szilvafajtákon. Kertgazdaság. 41. (2): 22-36.

Surányi, D. \& Erdős, Z. (1998): Szilva. [In. Soltész, M. (szerk.) Gyümölcsfajta- ismeret és -használat.] Mezőgazda Kiadó, Budapest. 258-287.

Surányi, D. Erdős, Z. (2006): Fontosabb szilvafajták. [In. Surányi, D. (ed.) Szilva.] Mezőgazda Kiadó, Budapest. 82-107.

Szabó, Z. (1991): Szilvafajták. Van választék. Kertészet és Szőlészet. 35: 20-22.

Szabó, Z. (2001): Szilva. [In. G. Tóth, M. (ed) Gyümölcsészet.] Primom Vállalkozásélénkítő Alapítvány, Nyíregyháza. 216-242.

Szabó, Z. (2004): Szilva. [In. Papp, J. (ed.) 2. A gyümölcsök termesztése.] Mezőgazda Kiadó, Budapest. 235-263.

Szabó, Z. Nyéki, J. (2006): A gyümölcs fejlődése. [In. Surányi, D. (szerk.) Szilva.] Mezőgazda Kiadó, Budapest. 168-171.

Szenci, Gy. (2006): A szilva betakarítása és a szüret utáni műveletek. [In. Surányi, D. (ed.) Szilva.] Mezőgazda Kiadó, Budapest. 274-280.

Usenik. V., Kastelec. D., Veberic. R. \& Stampar, F. (2008): Quality changes during ripening of plum (Prunus domestica L.). Food Chemistry. 111: 830-836. 